Article

\title{
Towards Sustainable Mining in the Didactic Process-MEITIM Project as an Opportunity to Increase the Attractiveness of Mining Courses (A Case Study of Poland)
}

\author{
Karolina Adach-Pawelus ${ }^{1}{ }^{\circledR}$, Anna Gogolewska ${ }^{1}{ }^{\circledR}$, Justyna Górniak-Zimroz ${ }^{1} \oplus$, \\ Juan Herrera Herbert ${ }^{2}$, Arturo Hidalgo ${ }^{2}$ (D) Barbara Kiełczawa ${ }^{1}(\mathbb{D}$, \\ Joanna Krupa-Kurzynowska ${ }^{1}{ }^{10}$, Matti Lampinen ${ }^{3}$, Maria A. Mamelkina ${ }^{3}$, \\ Gabriela Paszkowska ${ }^{1}$ (D), Danuta Szyszka ${ }^{1}$ (D), Ritva Tuunila ${ }^{3}$, Magdalena Worsa-Kozak ${ }^{1, *}$ (D) \\ and Justyna Woźniak 1,*(D) \\ 1 Faculty of Geoengineering, Mining and Geology, Wroclaw University of Science and Technology, \\ 50-421 Wrocław, Poland; karolina.adach@pwr.edu.pl (K.A.-P.); anna.gogolewska@pwr.edu.pl (A.G.); \\ justyna.gorniak-zimroz@pwr.edu.pl (J.G.-Z.); barbara.kielczawa@pwr.edu.pl (B.K.); \\ joanna.krupa-kurzynowska@pwr.edu.pl (J.K.-K.); gabriela.paszkowska@pwr.edu.pl (G.P.); \\ danuta.szyszka@pwr.edu.pl (D.S.) \\ 2 Escuela Técnica Superior de Ingenieros de Minas y Energía, Universidad Politécnica de Madrid \\ (Technical University of Madrid), 28003 Madrid, Spain; juan.herrera@upm.es (J.H.H.); \\ arturo.hidalgo@upm.es (A.H.) \\ 3 School of Engineering Science, LUT University, 53850 Lappeenranta, Finland; matti.lampinen@lut.fi (M.L.); \\ maria.mamelkina@lut.fi (M.A.M.); ritva.tuunila@lut.fi (R.T.) \\ * Correspondence: magdalena.worsa-kozak@pwr.edu.pl (M.W.-K.); justyna.wozniak@pwr.edu.pl (J.W.)
}

Received: 4 November 2020; Accepted: 30 November 2020; Published: 4 December 2020

\begin{abstract}
Mining has been embedded in the public consciousness as a dirty, non-innovative, outdated and environmentally harmful industry. Proper education, especially the academic one, becomes crucial to successfully change this image. This article depicts the initial assumptions of the international project Master in Entrepreneurship, Innovation and Technology Integration in Mining (MEITIM), co-financed by EIT Raw Materials, that aims to diagnose the current state of Polish higher education in the field of mining at, among others, the Wroclaw University of Science and Technology (WUST), concerning the experience of the Technical University of Madrid (UPM) and Lappeenranta University of Technology (LUT). The MEITIM project allowed identifying the directions of necessary changes in the didactic process as an indispensable set of skills and knowledge for a future mining graduate. Such activities are dictated by many guidelines and arrangements, among others, at the level of the European Commission or key industry institutions such as the International Council on Mining and Metals. These are key competencies that require significant changes in university curricula supporting sustainable development goals in innovative mining. The authors show that there is a link between the condition of the mining industry in Poland, its reputation, and the number of people who want to study mining.
\end{abstract}

Keywords: mining; higher education; statistics of mining faculties; raw materials; European Green Deal

\section{Introduction}

The implementation of the Master in Entrepreneurship, Innovation and Technology Integration in Mining (MEITIM) project is to indicate how to develop a new teaching offer aimed at innovative, 
sustainable and technologically advanced mining so that it can fulfill market requirements over the next 20-30 years. This article includes an introduction with an emphasis on the current guidelines of the European Commission on sustainable development policy together with the assumptions of the new growth strategy, which constitutes a European Green Deal for the European Union and its citizens. Particular attention should be paid to curriculum changes corresponding to these guidelines. The next part of the article contains the analysis of statistical data concerning the students and graduates of mining faculties in Poland over the last few years, taking the background of Finnish and Spanish compilations into account. Moreover, the authors analyzed the mutual relations between the condition and reputation of the Polish mining industry and the didactic offer of Polish universities and the choice of the field of study, indicating the reasons for the decreasing popularity of mining studies in Poland.

The innovative teaching process of the university should be based on the current guidelines of the European Commission concerning, among others, sustainable development policy linked to the assumptions of the new growth strategy, the so-called European Green Deal [1]. The prepared EU strategy assumes the transformation of the EU into a fair and prosperous society and its economy into a modern, competitive and resource-efficient one. To implement these guidelines, it is necessary to support the education of students and future engineers of the green economy. The mining industry faces a great challenge in the transition from a linear to a circular model. The authors of the paper [2] analyzed several EU guidelines aimed at accelerating the transformation in the area of a closed circular economy, which recommended the effective use of mineral resources in an era of sustainable development-environmental, economic and social. There are many challenges in the extractive industry, particularly achieving increased levels of critical raw materials (CRM), as well as the greater involvement of stakeholders themselves and raising the awareness of sustainability among extractive companies. The inclusion of these issues in the educational offer of Polish technical universities, necessary in the context of the challenges that sustainable development poses to industry staff and the graduates of these universities, is depicted in the paper [3]. The research on study programs and the additional educational offer of 18 state technical universities in Poland shows that they do not fully correspond to the identified trends. For a proper organization of the formula of teaching about social responsibility, this should be supported by an analysis of stakeholder needs. A similar form of need analysis was carried out by the research [4], addressed to two groups of stakeholders, i.e., mining students at the Wroclaw University of Science and Technology and mining industry employees. The study aimed at examining knowledge on corporate social responsibility (CSR) in two groups, indicating the need to include issues related to sustainable social and environmental responsibility in the program of technical studies with a mining profile. The research results indicated that increasing the knowledge of mining students in this area will be accompanied by increased awareness among (future) industry employees and the public. This may mean increasing expectations towards enterprises, in the form of raising standards concerning the natural environment, working conditions, as well as social dialogue. These issues correspond, among others, to the guidelines of the International Council on Mining and Metals (ICMM). Sustainable mining is manifested in ten principles of the ICMM [5], which strengthen social and environmental management requirements for the industry. The detailed guidelines are aimed at:

1. Ethical business practices in management and transparency to support sustainable development;

2. Sustainable integration of corporate strategy into decision-making processes;

3. Respect for human rights and interests, cultures, customs and values of employees and communities;

4. Implementation of effective risk management strategies and systems;

5. Improving health and safety performance;

6. Sustainable environment (water management, energy efficiency, emissions, etc.);

7. Protection of biodiversity and integrated approaches to spatial planning;

8. Responsible production-implementing the closed-loop concept; 
9. The social aspect, integrated approach to local communities;

10. Management of stakeholder groups, implementation of the Extractive Industries Transparency Initiative (EITI), the indication of the Global Reporting Initiative (GRI) guidelines in reporting.

The challenges faced by the mining industry require changes in the education of future employees of one of the main departments (not only) of the Polish economy, in the following years. The didactic process requires transformation towards sustainable development by updating fields and subjects in line with the latest trends. The ongoing INTERMIN project, within the framework of Horizon 2020, involves educational and research institutions based on the expertise of individual countries, in the direction of, e.g., identifying the necessary skills in the primary and secondary raw materials sector. In one of the project reports [6] the skills were grouped as follows:

1. Technical (digitization of operational processes);

2. Soft skills (understanding and implementation of sustainable development principles, leading social aspect);

3. Understanding the principle of a closed-loop economy (research and development in the field of new materials and new processes, environmental issues).

The INTERMIN project results published in the paper by [7], point out that most of the "soft skills" in the business management and social aspects related to raw materials education seem to be under-represented compared to technical skills. According to the authors, feedback obtained from surveys conducted among students of mining indicates deficiencies in developing and non-technical skills, such as communication and management. In turn, the work of [8] highlights the role of new digital technologies as leading skills in real-time data processing, reporting and monitoring exploration, planning, extraction, production and marketing. In the further part of the article, the authors point out the need to train mining industry professionals with the implementation of the problem-based learning method to face the technological challenges related to the mining market. Together with [9], they highlight the role of the extractive industry in a much broader economic and technological ecosystem, indicating the Global Reporting Initiative (GRI) guidelines as a tool for transparency in reporting and disclosing sustainability information.

The MEITIM international project is an initiative that aims to combine the latest international trends with the challenges of the extractive industry. The international cooperation in the project will allow adapting the teaching offer aimed at sustainable mining as a process of providing new skills and competencies for graduates adapted to the evolving market requirements.

\section{Mining Sector in Poland}

Data on the mining sector in Poland were collected from [10-14] and [15,16], available at [17]. The data refer to business entities conducting activities in Poland classified following the Polish Classification of Economic Activities (PKD) developed on the ground of the Statistical Classification of Economic Activities in the European Community-NACE Rev. 2. PKD 2007 was introduced on 1 January 2008 by the Regulation of the Council of Ministers of 24 December 2007 [18]. Within the framework of PKD 2007, the following activity was distinguished: industry-which included, among others, the sections: Mining and Quarrying. The data collected as part of the research cover the years 2008-2018 and provide information on employment and redundancies in the mining sector in Poland.

Data on employment in the Mining and Quarrying are divided into enterprise ownership sectors, i.e., the public sector grouping state ownership (of the State Treasury and state legal persons), ownership of local government units and "mixed ownership" with a predominance of capital (property) of public sector entities and the private sector grouping domestic private ownership (natural persons and other private entities), foreign ownership (foreign persons) and "mixed ownership" with a predominance of capital (property) of private sector entities. "Mixed ownership" is mainly defined for companies and is determined by the capital (property) structure declared in the company registration 
application. Figure 1 shows the number of people working in the Mining and Quarrying section with a breakdown by business ownership sectors.

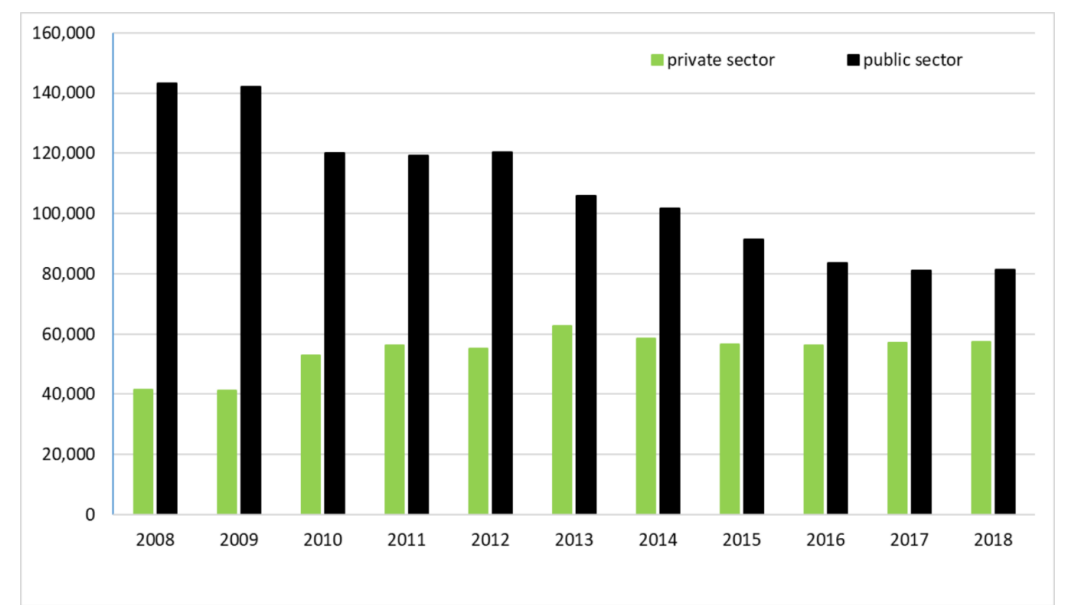

Figure 1. Number of employees in the Mining and Quarrying section during the period 2008-2018 by ownership sectors (own elaboration based on Central Statistical Office (CSO) data).

The next chart (Figure 2) presents data on people admitted to work as full-time employees in enterprises, without economic entities with up to nine employees in the Mining and Quarrying section (including graduates of universities, post-secondary, secondary and primary schools taking up work for the first time in this section). Unfortunately, there is no precise division into graduates employed after mining schools (vocational schools, technical schools and universities educating graduates in mining subjects).

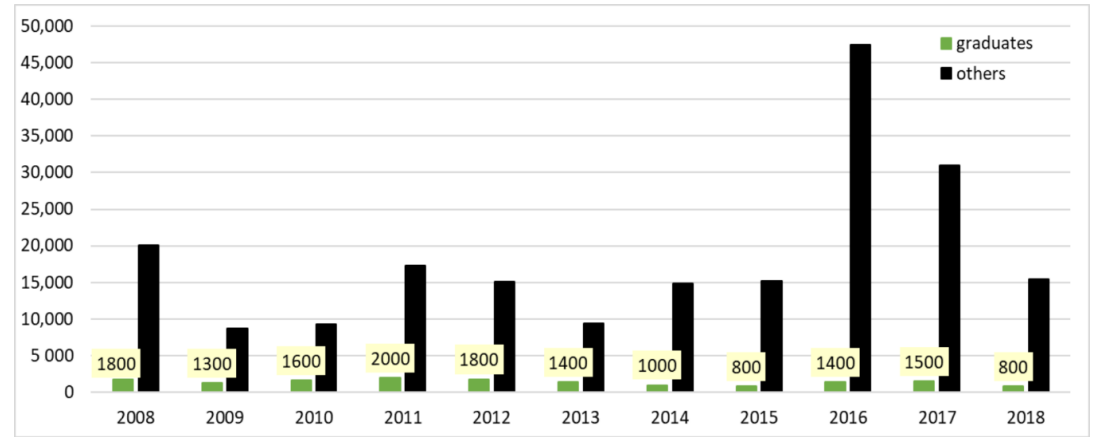

Figure 2. The number of employees in the Mining and Quarrying section during the period 2008-2018 (own elaboration based on CSO data).

Data on the employees made redundant in the Mining and Quarrying section in enterprises without economic entities with up to 9 employees, broken down by the cause of the redundancy, are presented in Figure 3. The breakdown shows the redundancies by notice of termination by the employer or the employee and the employee's retirement, incapacity pension or rehabilitation. 


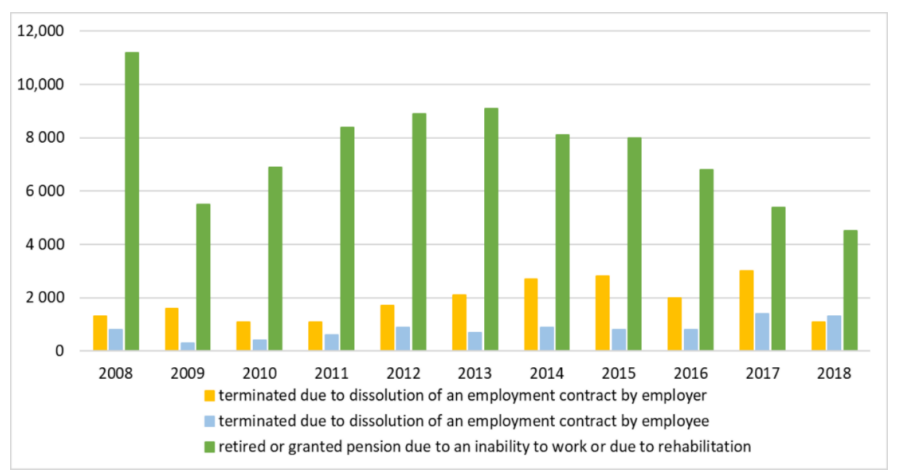

Figure 3. The number of employees made redundant in the section Mining and Quarrying during the period 2008-2018 because of dismissal (own elaboration based on CSO data).

\section{Academic Statistics}

\subsection{Poland}

Data on graduates completing studies in Mining and Geology were obtained from three state universities: AGH University of Science and Technology in Krakow, Silesian University of Technology and Wroclaw University of Science and Technology. The data cover the years 2009-2019, i.e., the academic years: 2009/2010, 2010/2011, 2011/2012, 2012/2013, 2013/2014, 2014/2015, 2015/2016, 2016/2017, 2017/2018 and 2018/2019.

During the period 2009-2019, the AGH University of Science and Technology offered Mining and Geology studies at three faculties: Faculty of Mining and Geoengineering (specializations: Exploitation of Mineral Deposits, Geoengineering, Underground Mining, Opencast Mining, Mechanical and Electrical Engineering in Mining, Processing of Mineral Resources, Mining Geomechanics and Underground Construction, Mining Engineering), Faculty of Geology, Geophysics and Environmental Protection (specializations: Economic Geology, Mining Geology, Geology and Deposit Prospecting, Engineering Geology and Geotechnics, Oil Geology, Hydrogeology and Engineering Geology, Geological Cartography, Applied Mineralogy with Gemology) and the Faculty of Drilling, Oil and Gas (specializations: Drilling and Geoengineering, Liquids Exploration, Natural Gas, Environmental Protection in the Economy, Water Management and Protection). Figure 4 shows the number of students that graduated in Mining and Geology during the analyzed period, by faculty.

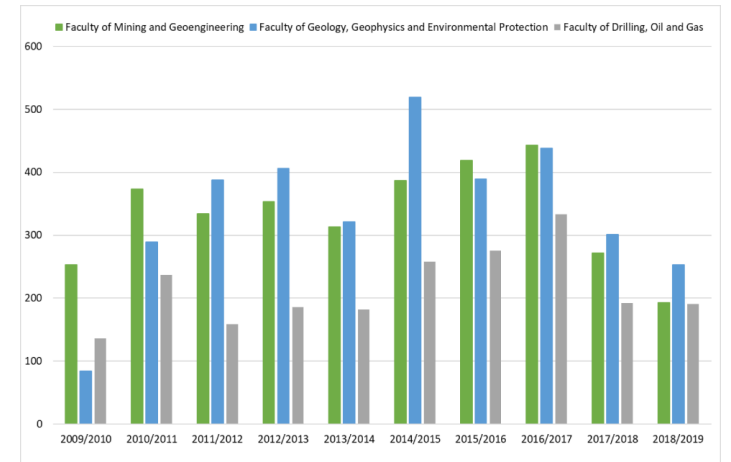

Figure 4. Graduates in Mining and Geology of the AGH University of Science and Technology in Krakow during the period 2009-2019.

In the years covered by the research, the AGH University of Science and Technology educated students undertaking full-time uniform master's degree courses (until the academic year 2012/2013), full-time studies of the first and second degree and part-time studies of the first and second degree. 
Figures 5-7 show the number of students graduating in Mining and Geology at individual faculties, with a breakdown by the degree and by Polish and foreign students.

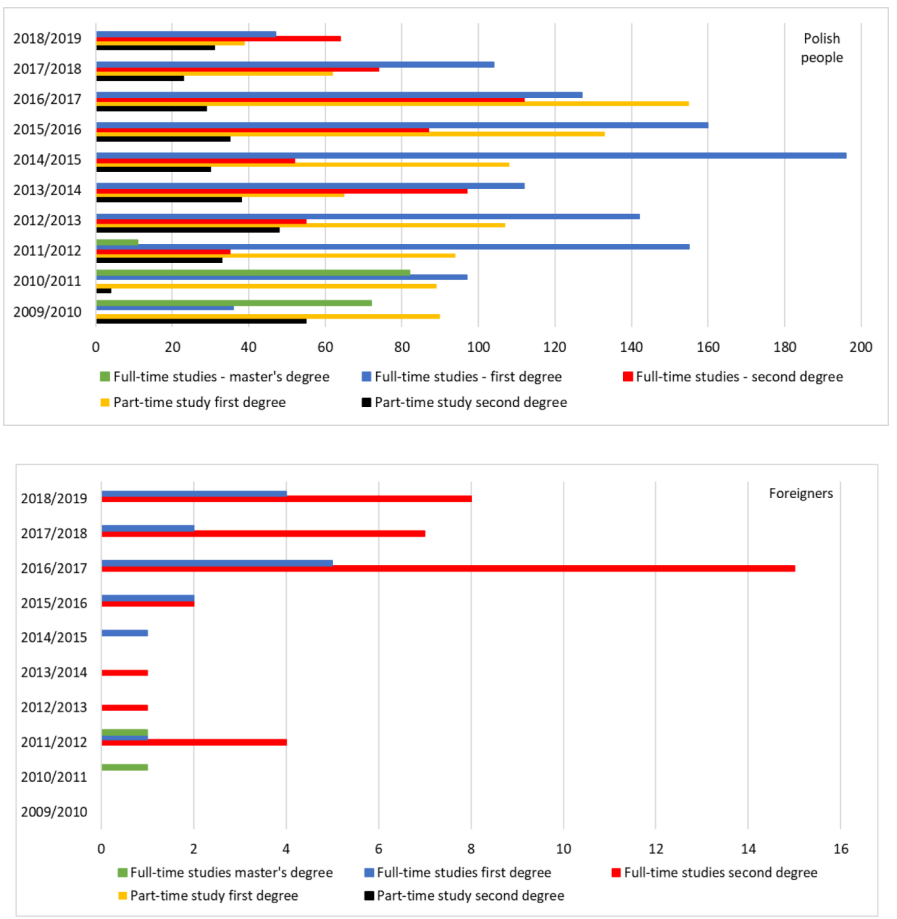

Figure 5. Graduates in the Mining and Geology of the Faculty of Mining and Geoengineering of the AGH University of Science and Technology in Krakow during the period 2009-2019, by the degree of education.

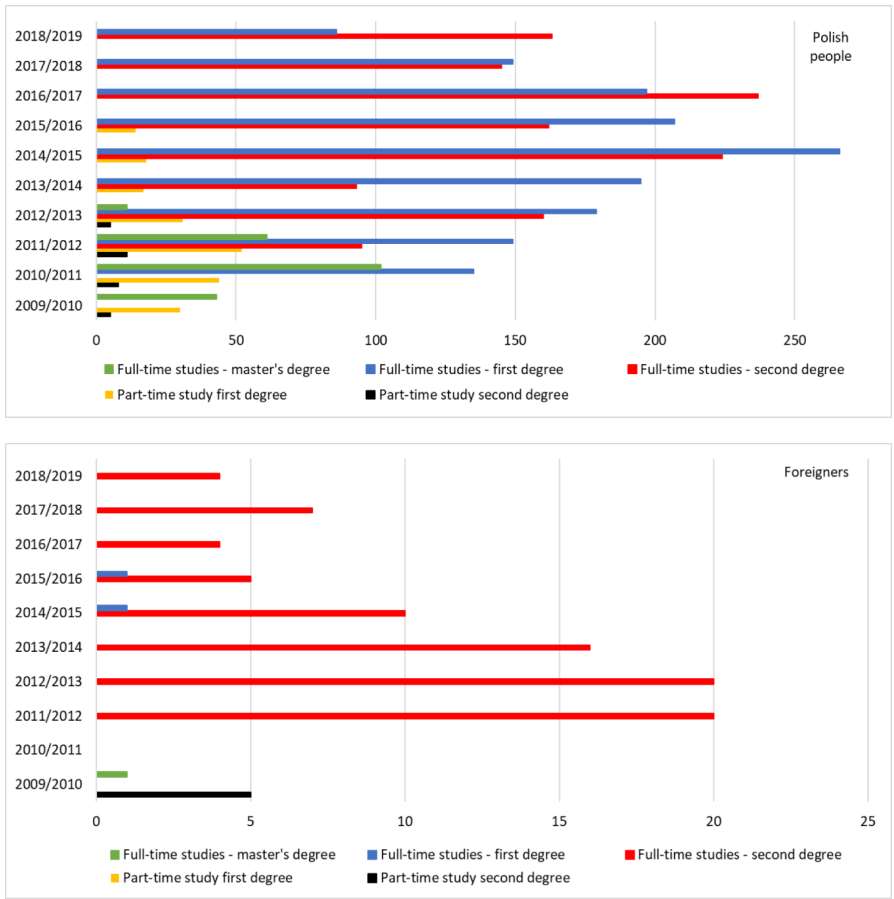

Figure 6. Graduates in Mining and Geology of the Faculty of Geology, Geophysics and Environmental Protection of the AGH University of Science and Technology in Krakow during the period 2009-2019, by the degree of education. 


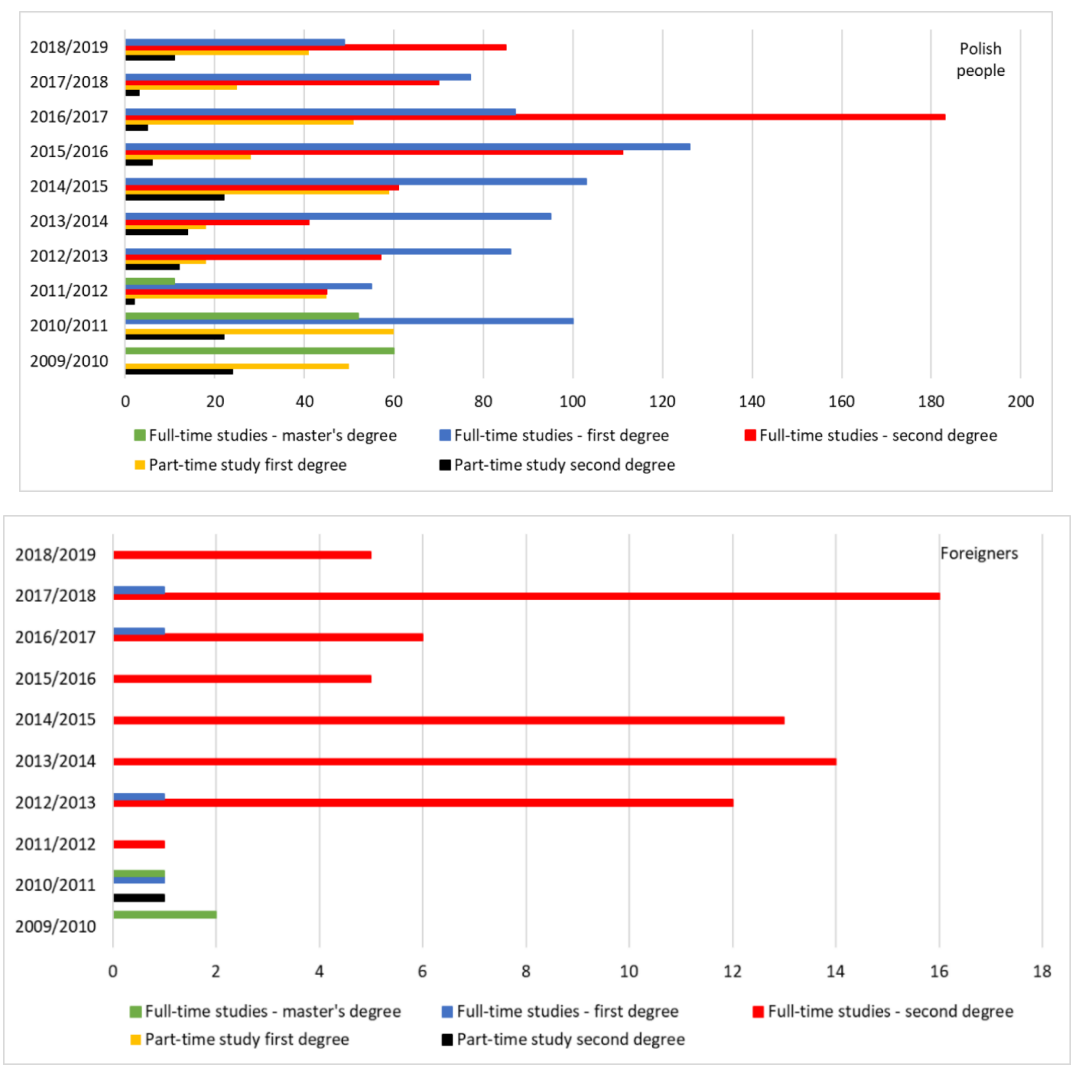

Figure 7. Graduates in Mining and Geology of the Faculty of Oil and Gas Drilling of the AGH University of Science and Technology in Krakow during the period 2009-2019, by the degree of education.

During the period 2009-2019, Wroclaw University of Science and Technology offered studies at the Faculty of Geoengineering, Mining and Geology in full-time and part-time studies of the first and second degree in the specializations: Geoengineering, Geoengineering and Environmental Protection, Exploration and Mining Geology, Open-pit Mining, Underground Mining, Underground and Open-pit Exploitation of Deposits. Figure 8 shows the number of graduates completing the studies in each degree.

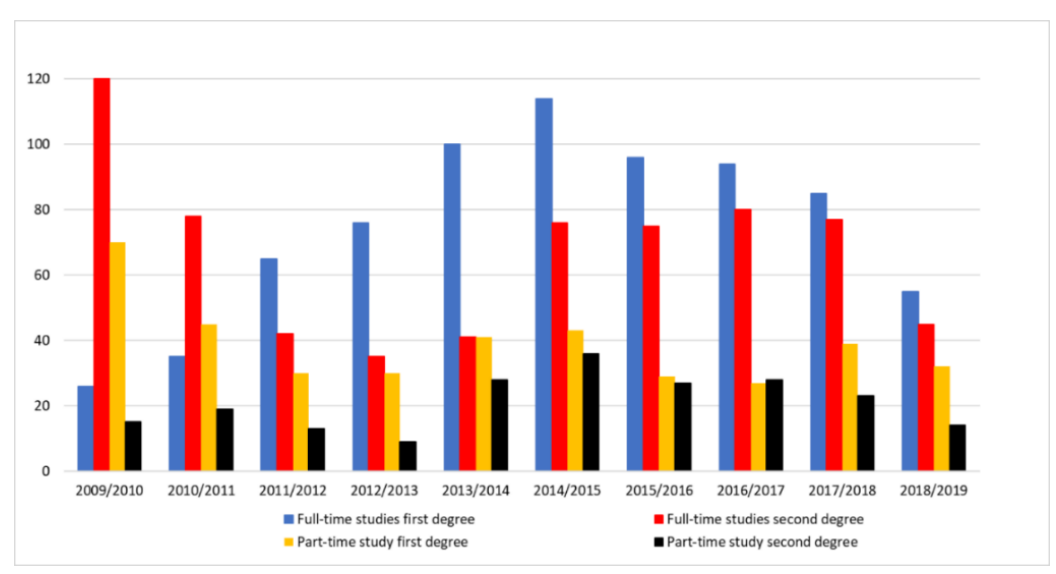

Figure 8. Graduates in the Mining and Geology of the Faculty of Geoengineering, Mining and Geology of the Wroclaw University of Science and Technology during the period 2009-2019 by the degree of education.

During the period 2009-2019, the Silesian University of Technology and the Faculty of Mining, Safety Engineering and Industrial Automation offered studies in Mining and Geology in thirteen 
specializations: Underground Construction and Surface Protection, Electrical Engineering and Automation in Mining (until 2012 for Automation and Power Engineering in Mining), Deposit Extraction and Waste Management, Mining Surveying, Mining and Exploration Geology, Engineering Geology and Geotechnics, Water Management, IT and Management in the Mining Industry (until 2012 for Organization and Economics in the Mining Industry, and 2012-2018 for Managerial Management in the Mining Industry), Environmental Shaping in Mining Areas, Mining, Construction and Road Machinery, Mining and Drilling Machinery and Equipment, Solid Mineral Processing and Marketing, Occupational Health and Safety Technology and Organization. These studies were held on a full-time and part-time basis as first and second-degree studies. Figure 9 shows the number of graduates completing their studies in Mining and Geology during the analyzed years, with a breakdown by degree. Figure 10 shows a list of graduates from three state universities in Poland offering studies in Mining and Geology during the period 2009-2019.

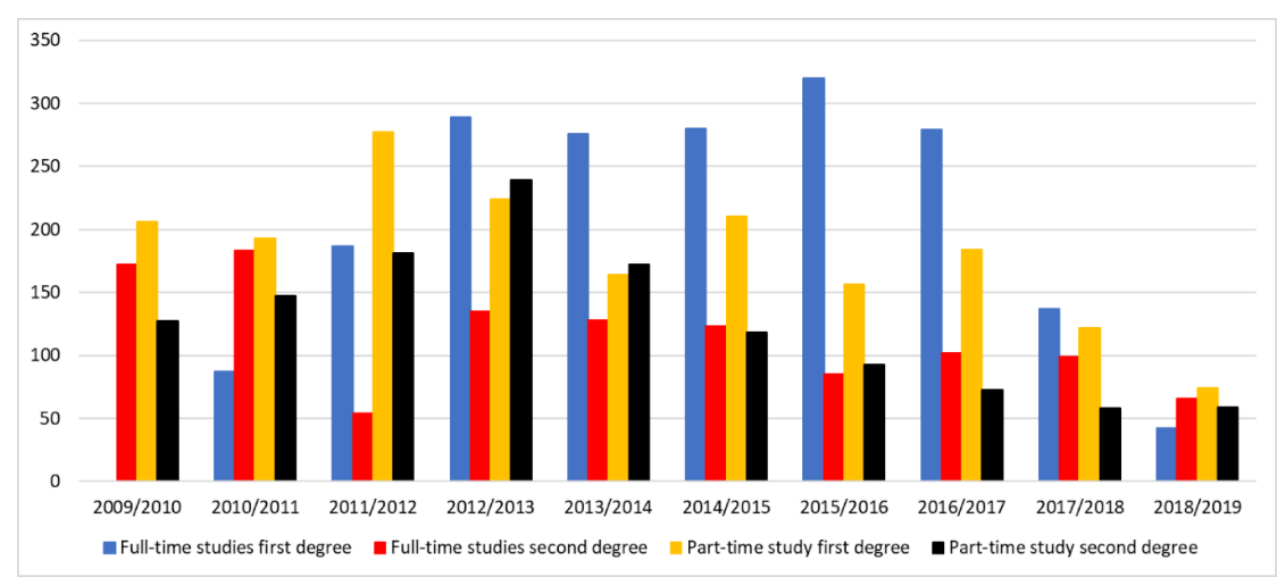

Figure 9. Graduates in Mining and Geology of the Faculty of Mining, Safety Engineering and Industrial Automation of the Silesian University of Technology during the period 2009-2019, with a breakdown by the degree of education.

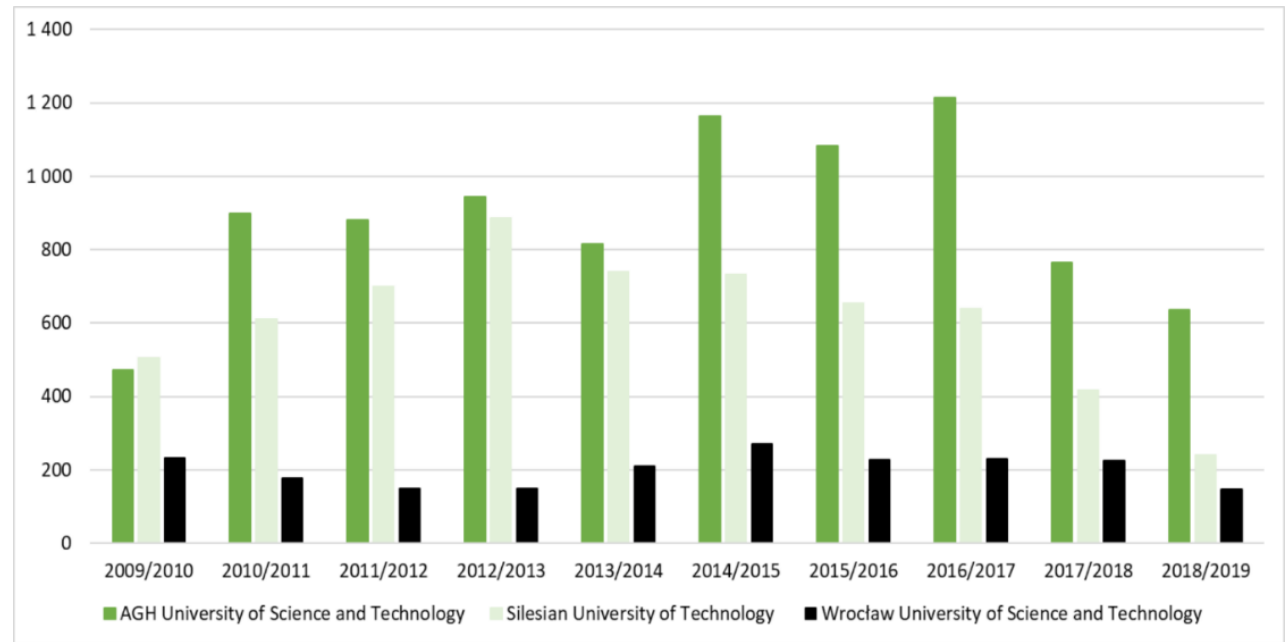

Figure 10. Graduates in Mining and Geology completing their studies during the period 2009-2019 at state universities in Poland.

\subsection{Spain}

In Spain, mining has been taught in 14 schools, distributed between 13 universities throughout the country (Figure 11). Of these, the most notable by tradition and number of students is the Higher Technical School of Mining Engineers of the Technical University of Madrid (Universidad 
Politécnica de Madrid UPM, according to Spanish denomination). Created in 1777, during the reign of Carlos III, in Almadén (Ciudad Real), it was one of the first in Europe, just ten years after the creation of the first Academy of Mines of Freiberg (Saxony). It was moved to Madrid in 1835, where it had different provisional locations. In 1893, the school was definitively installed in its present place. Nowadays, the school is fully integrated into the European Higher Education Area (EHEA). In Spain, there is no professional qualification as there is in other countries, but there is a legal regulation that covers this requirement and the requirement to sign a graduate in mining engineering projects.

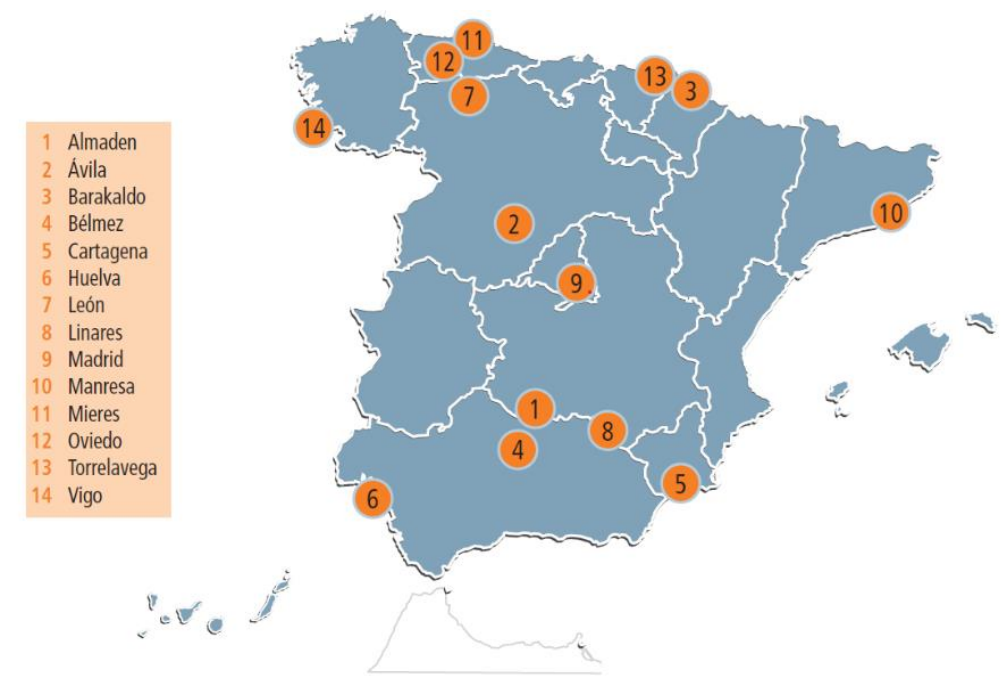

Figure 11. Location of the 14 schools of engineering that provide mining education in Spain.

Since the implementation of the European Higher Education Area, the current model in Spain is that of a 240 ECTS (European Credit Transfer System) bachelor's degree (specialized), followed by a transversal master's of 90 ECTS in most schools, or 120 ECTS as is the case of the Technical University of Madrid. The old degrees with various specializations were transformed into various bachelor's degrees, which reduced the number of students of Mining Engineering as new degrees in Energy, Geological Engineering and Metallurgical Engineering were created. In all cases, the educational model is the training based on learning outcomes, the development of skills by the student, with training objectives based on the development of generic skills, but also professional skills specific to the degrees. This has allowed the formulation of specific and transparent quality indicators. The model also facilitates, especially at the UPM, the students' mobility as an integral part of their training development and work placements [19-22].

In the schools as a whole, the demand for the title of Mining Engineer has been progressively decreasing in recent years (Figure 12), although at the same time there has been growth at the Polytechnic University of Madrid, achieved thanks to a diversification of degrees. The demand for Mining titles constitutes a weak point among these degrees. 


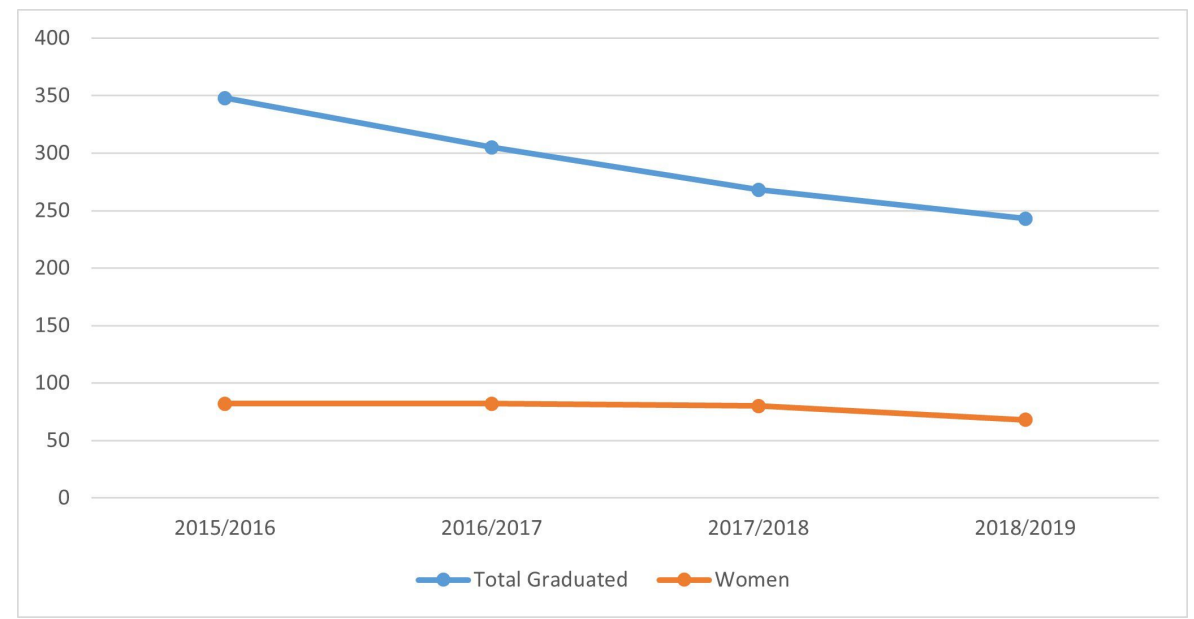

Figure 12. Evolution of graduates of bachelor's degrees in Mining Engineering in Spain in recent years and the total number of women.

Figures 12 and 13 present the evolution of graduates of bachelor's degrees in Mining Engineering and the evolution of graduates of M.Sc. studies in Mining Engineering, respectively. It can be seen that the total number of graduates is decreasing, both in bachelor's and master's, although the number of women remains more or less constant.

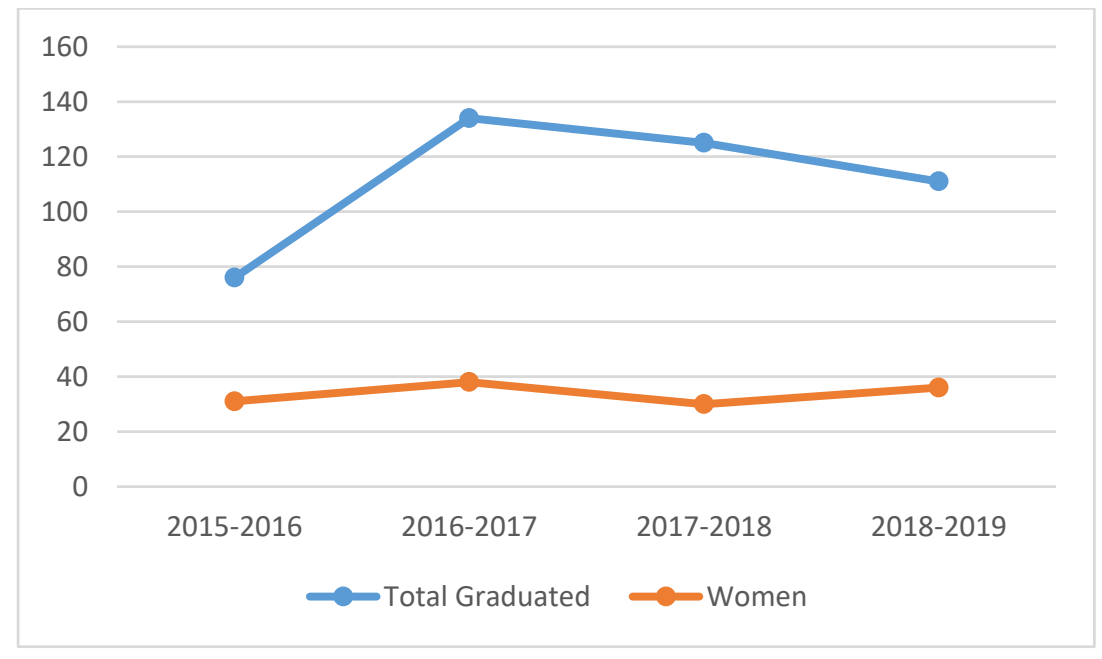

Figure 13. Evolution of the graduates in M.Sc. studies in Mining Engineering in Spain and the evolution of the number of women.

Some of the reasons that can explain this situation are the following:

- University education offering has not stopped growing in recent years;

- The appearance of degrees in great demand because they are associated with technological or environmental development;

- The degree is less attractive to society-there is a misperception that these are titles with a limited scope and in recession.

Figures 14 and 15 depict the contribution of several Spanish Universities to the total number of graduates of the different mining degrees, referred to as bachelor's and master's studies, respectively. It can be observed that, in the case of bachelor's studies (Figure 14), the main contributor is the School of Mining Engineers of Technical University of Madrid, followed by the University of Oviedo. The reason behind this is that, apart from the fact that Madrid is the capital of Spain and the most populated city, 
both Madrid and Oviedo were the two former places which offered Mining Engineering studies. We recall here that, as aforementioned, the school of Madrid was founded in the 19th century on the ground of the previous School in Almadén. Concerning master's studies (Figure 15), again the Technical University of Madrid is the main contributor although, in this case, the University of León is placed in the second position, locating the University of Oviedo in the third place. It can be noticed that both León and Oviedo belong to regions with a strong mining tradition, mainly focused on coal. The Universities of Andalucía (Huelva, Jaén and Córdoba) are also of certain importance. This is due to a mining tradition, as well, but especially referred to as metallic mining.

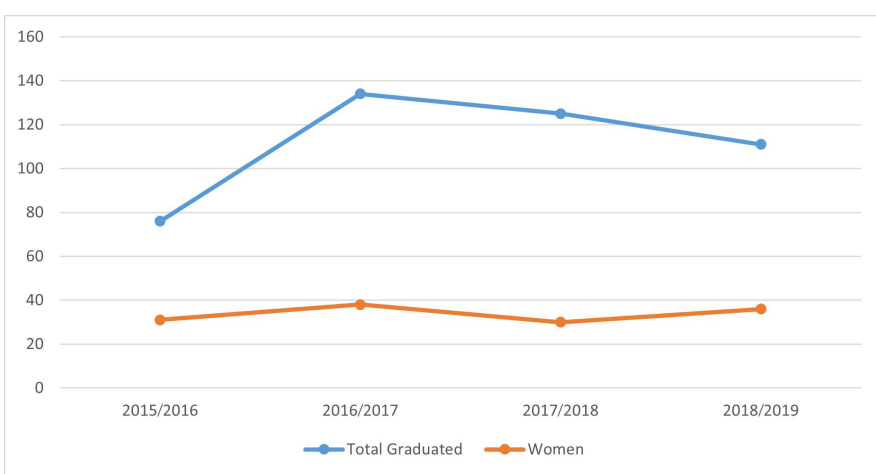

Figure 14. Contribution of several Spanish universities to the total number of graduates of the different mining degrees. Bachelor's results are shown.

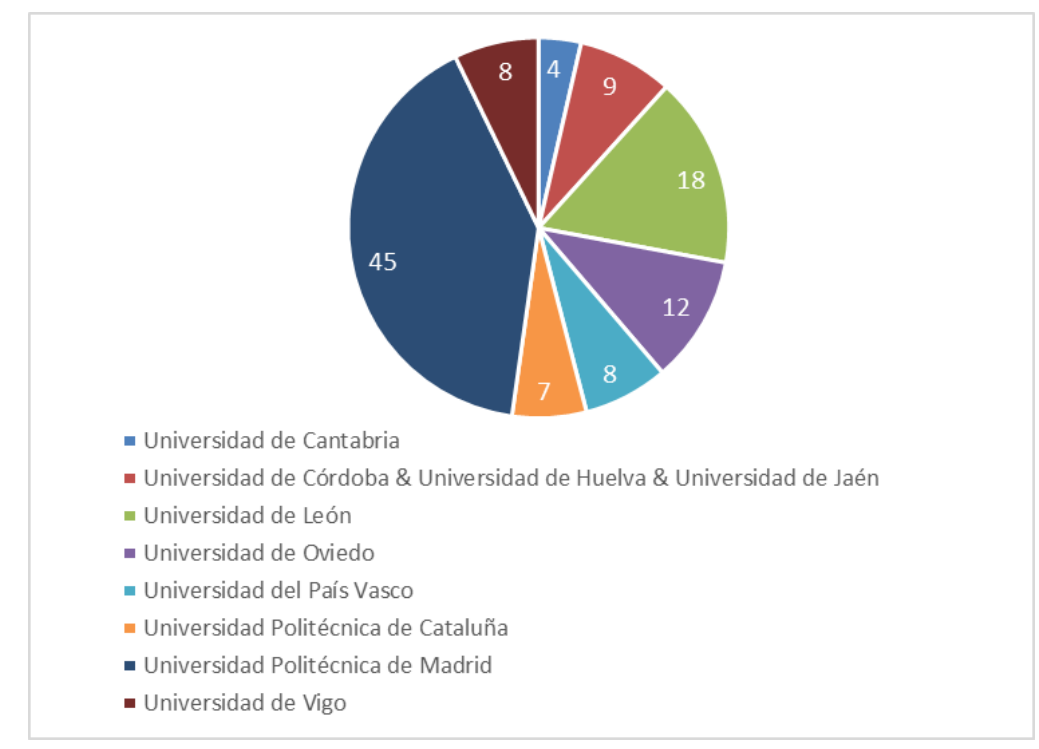

Figure 15. Contribution of several Spanish universities to the total number of graduates of the different mining degrees. Master's results are shown.

Contribution of Spanish universities to the number of graduates of M.Sc. degrees in mining education (2018-2019).

In Spain, as in the rest of Europe, the image that society has of this degree does not correspond to its reality in terms of employment prospects and scope of professional activity. Unfortunately, this image is significantly widespread, and it is difficult to fight against it, despite the efforts that many universities are making to attract new students. This situation is supposing the disappearance of specialties in some schools and could even suppose if maintained, the disappearance of degrees in others that have low demand and/or a high supply of specializations.

However, the perspective that exists from within the universities in terms of job opportunities and professional prospects of their graduates is different since, over the years, although there are no 
contrasted statistical figures, a favorable difference appears between the number of graduates and the number of professionals hired for whom it is essential to have these degrees. Employment occurs mainly in sectors of activity typical of these engineering companies or related to them, however, if other non-specific jobs that are also filled with graduates of the schools are included in the analysis, it is understood that despite appearances, graduate students continue to find a large number of opportunities both within and outside of Spain. The breadth and quality of the theoretical and practical knowledge that they receive during their academic training make them very versatile, generalist and prestigious technicians, which is why these graduates constitute a group with a good rate of employment. On many occasions, this insertion is done through self-employment. Consequently, the labor market situation for these degrees does not allow a moderate increase in the supply of graduates but does demand new degrees of specialization and professional training.

Figure 16 shows the evolution of an M.Sc. in Mining Engineering studies in four different Spanish universities (León, Oviedo, Vigo and Madrid) [19-22]. It can be seen that only in Madrid there is an increment of students, whereas in the others, the evolution tends to be constant or decreasing. The reason for this increment in Madrid may be due to the wide range of bachelor's degrees offered by the School of Mining Engineers, which may lead to an increase in students with M.Sc. studies.

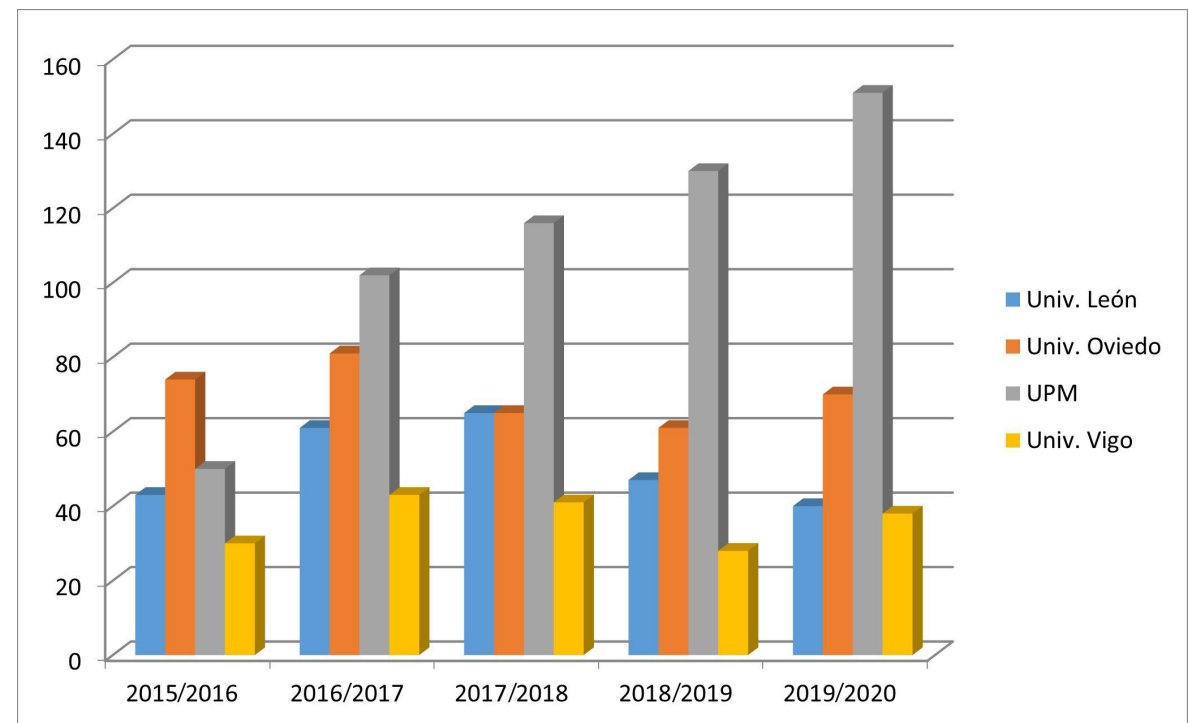

Figure 16. Evolution of M.Sc. Mining Engineering students in four Spanish universities (León, Oviedo, Vigo and Technical University of Madrid (UPM)).

The recruitment of good students is an essential condition to guarantee the success of the training program. The goals would not be adequately achieved without capable, dedicated and convinced students to whom engineering offers a very interesting field for personal development and high-level intellectual creation.

\subsection{Finland (Statistics of LUT Chemical Engineering Graduates 2017-2020 and Data from University of Oulu)}

This part presents data from two Finnish universities: the University of Oulu and Lappeenranta University of Technology (LUT). The University of Oulu has a mining program. The data were prepared separately for bachelor's and master's programs. Figure 17 contains students starting in bachelor's programs of Geosciences and Geophysics (Geo) as well as Mining Technology and Mineral Processing (MTaMP) during the period 2014-2020. 


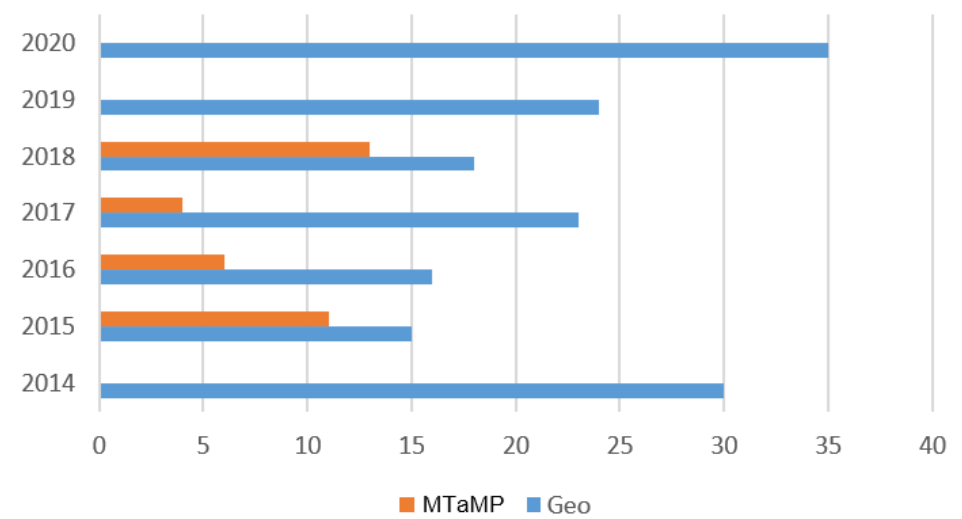

Figure 17. Students starting in bachelor's programs of Geosciences and Geophysics (Geo)/Mining Technology and Mineral Processing (MTaMP).

Figure 18 refers to master's students starting their education in the last 7 years. These numbers 2014 (37), 2015 (23) and 2016 (25) include students in the B.Sc. program who already are undertaking M.Sc. level studies.

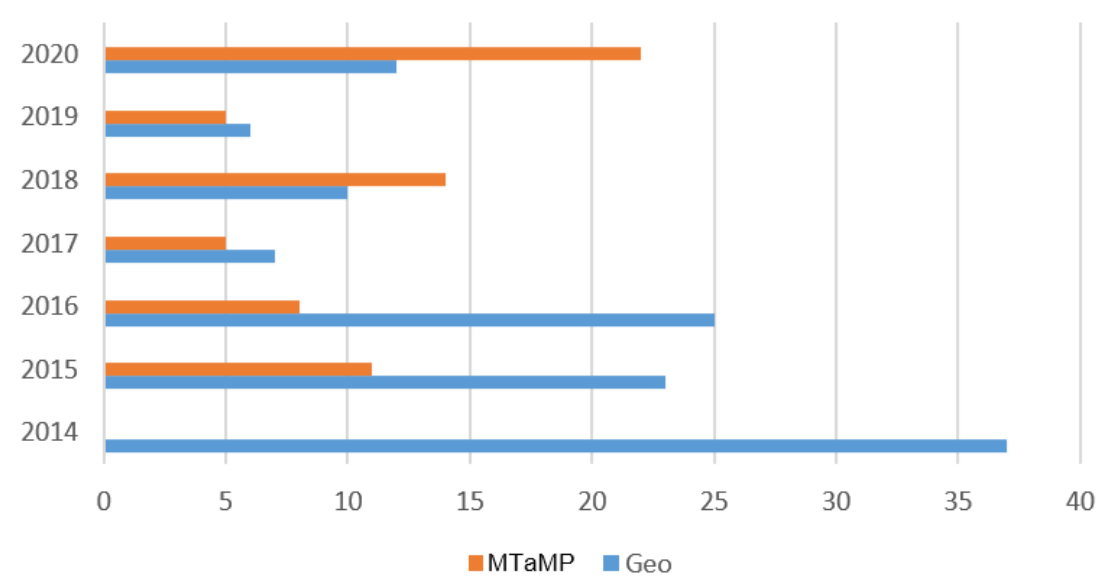

Figure 18. Students starting in the master's program of Geosciences and Geophysics (Geo)/Mining Technology and Mineral Processing (MTaMP).

The statistics of graduates in the above fields of study of the Oulu University at particular levels are presented in Figure 19.

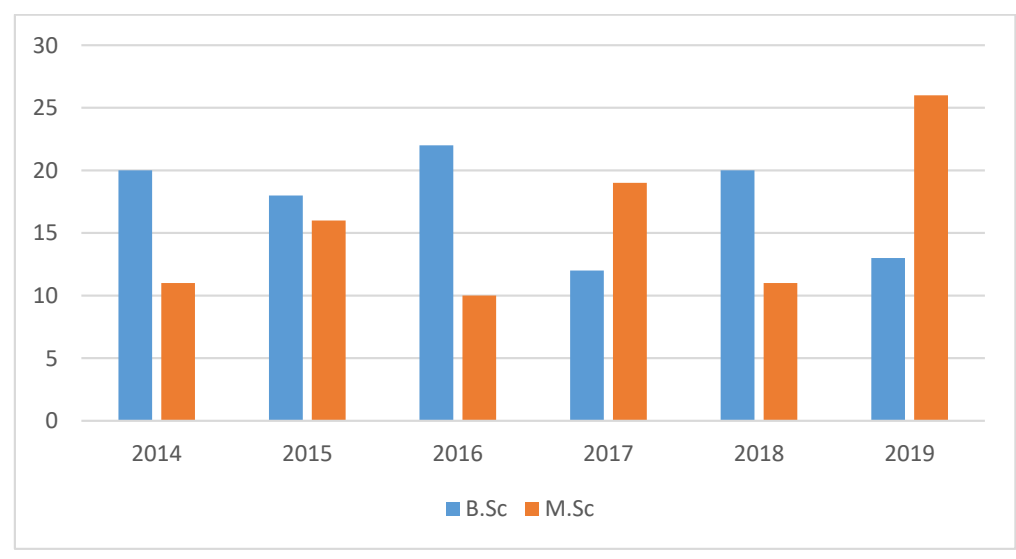

Figure 19. The number of graduates of the Oulu University of Geosciences and Geophysics (Geo) and Mining Technology and Mineral Processing. 
At LUT, the Master in Chemical Engineering thesis can be done in the company, at the university or in another research institute. Students are supposed to be active and seek topics for their theses by themselves. Sometimes the companies advertise open master's thesis positions via LUT Career services offering LUT REKRYNET service, professors or some other contact person at the university. Professors may also have some topics related to ongoing research projects. The course master's thesis and seminar constitute an e-learning course implemented in the Moodle platform. This course is developed for supporting students in starting and doing theses and it is obligatory for all students. Sometimes open thesis positions, either from the industry or university, are announced also on that platform, but there is not any list of possible topics offered by a degree program from which students just could select some. Of course, a student always can suggest a topic by themself, but then usually the thesis is unpaid as it can sometimes also be in a case where a student has not found a topic anywhere and is willing to start a thesis for some topic negotiated with a professor.

Data on accepted master's theses in chemical engineering of LUT were obtained for the academic years 2017/2018, 2018/2019 and 2019/2020. During the studied period, 163 master's students graduated from LUT Chemical Engineering. Ninety master's theses, i.e., 55.2\% of them, were undertaken directly for the industry. The total amount and the number of theses done for the industry in different academic years are presented in Figure 20.

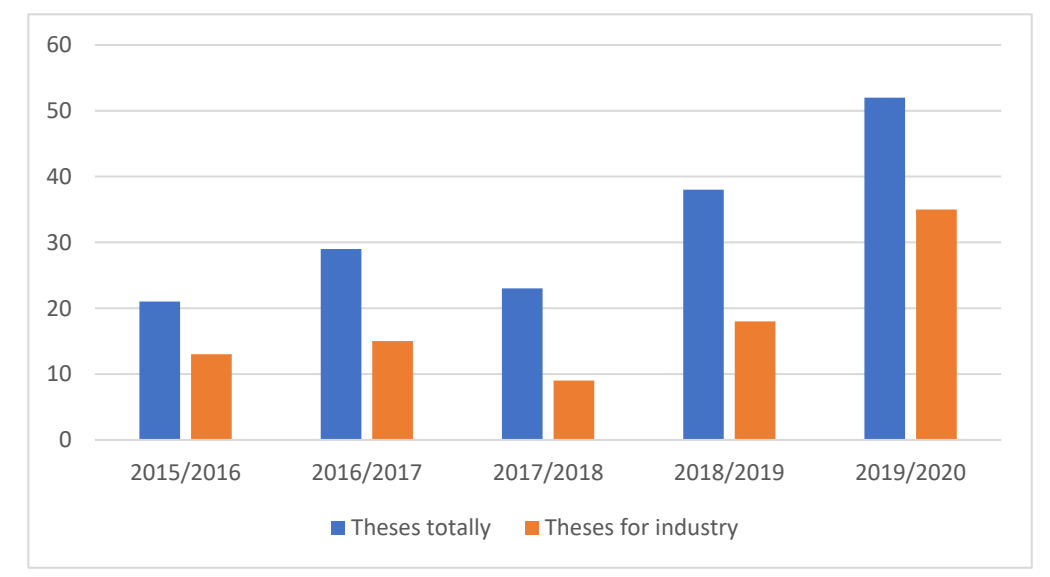

Figure 20. The number of accepted master's theses and those done for the industry at LUT Chemical Engineering during the academic years 2015/2016-2019/2020.

In Finland, the tradition is that in the field of engineering master's theses are most often performed within the industry or with the research projects at the university, paid with a salary or scholarship. The high amount of theses performed at the university in recent years can be explained by that nowadays $30-40 \%$ of Master in Chemical Engineering students per cohort are international, who have had difficulties to find thesis positions in the Finnish industry and thus, they have most often done their thesis for the topics related to university research projects or suggested by some professor. It must be noted that many theses that are done for some university projects also have a connection with the industry, as well because most of the projects are done in cooperation with industrial partners, who usually fund the projects totally or partly. Thus, it can be assumed that generally, about $70 \%$ of the theses have industry connections in one way or another. The number of theses done for the mining industry during these five years was 14 ( $8.6 \%$ of all) while the majority was done for the chemical and forest industry.

\section{Project MEITIM-Main Goals and Assumptions}

For many years, the Wroclaw University of Science and Technology (WUST) has been carrying out activities and projects aimed at, firstly, making mining studies more attractive and encouraging secondary school students to undertake them, and secondly, and most importantly, educating graduates 
with competencies meeting the future needs of employers. The first such activities were already undertaken in 2002 when the university joined the international program European Geotechnical and Environmental Course (EGEC), later transformed into one of the specializations within the EMMEP (Erasmus Mundus Minerals and Environmental Programme). Another program replacing EMMEP was the European Mining, Minerals and Environmental Programme (new EMMEP), which allowed three partner universities (TU Delft, Aalto University, University of Miskolc, RWTH Aachen University and Wroclaw University of Science and Technology) to obtain a diploma in one of three specializations. This program was very popular with Polish students. The internationalization of education combined with work placements held in many countries allowed the graduates of this program to find jobs in the mining sector not only in Poland but also in global mining concerns all over the world. During their studies, young people gained the necessary professional experience, learned about the cultures and customs of other countries and the principles of working in international companies. They obtained a unique competitive advantage and are now the backbone of the engineering staff of many companies in Europe, Australia, the United States and Canada. Unfortunately, the program ended in 2015 as a result of the difficult situation in some of the partner institutions and the associated drop in the number of willing students.

The experience in the internationalization of the teaching offer gained before 2015 allowed the Wroclaw University of Science and Technology to smoothly enter educational projects dedicated to the raw materials industry, which received co-financing from the EIT KIC (Knowledge and Innovation Community) Raw Materials. These included the Circular Economy Design Forum (CEDF)—since 2016; Circular Economy Entrepreneurship in System Integrated Metals Processing (CEE SIMP 2)—since 2017; Circular Economy Entrepreneurship in System Integrated Metals Processing (CEE SIMP 3)—since 2018; EC-Geo-Sustain-M.Sc. in Geomatics for Sustainable Mineral Resource Management-since 2018; Open YourMine—started in 2019 and MOBI US—started in 2020. All the aforementioned projects were or are only complementary to the educational offer of the Faculty of Geoengineering, Mining and Geology and do not solve the problem of decreasing the number of candidates for studies, especially master's studies.

However, the latest challenges faced by the mining industry, as described in this article, require significant changes in academic education in mining studies. A new approach to education is needed, especially in upper secondary studies, taking into account the competencies necessary for the mining of the future. The answer to these challenges is the latest international MEITIM project-Master in Entrepreneurship, Innovation and Technology Integration in Mining, conducted under the leadership of the Technical University of Madrid (Spain) in partnership with Wroclaw University of Science and Technology (Poland) and Lappeenranta University (Finland) and partners from the entire knowledge and innovation triangle: Agencia Estatal Consejo Superior de Investigaciones Cientificas M.P., CSIC (The Spanish National Research Council, Atlantic Copper S.L.U., Geologian tutkimuskeskus, GTK (Geological Survey of Finland), Metso Minerals Oy, Outotec (Finland) Oy, Suomen Malmijalostus Oy (formerly Terrafame Group Oy).

This project is co-financed by EIT Raw Materials (contract no. 19116) under KAVA call 6, area D3 RM Academy, segment D3.2 master's education, with the strategic objective of securing raw materials supply.

The main objective of the project is to create from scratch a completely new master's degree program, which will combine entrepreneurship, innovation and technology integration in the mining industry. The project is intended to last four years and includes the opening of the first call for new studies and a pilot year of the course.

The project includes the development of a feasibility and market study and, above all, the definition of a completely new master's program (120 ETCS) under the EIT Label. These studies will educate a new generation of technologists and entrepreneurs, who will have a broad horizon, understand the whole value chain of raw materials and be capable of integrating innovation and new technologies 
into real industrial and business applications. The sustainable, modern and green mining of the future must be based on properly educated personnel, and that is what the MEITIM project wants to provide.

The raw material industry is currently focusing on digitization and automation, the implementation of the Industry 4.0 concept or intelligent mining. Unfortunately, there is no master's program which includes the integration of modern technologies into the raw materials industry and trained specialists in this area who are also able to turn practical implementation of innovations into a competitive advantage for the company and an element of strategic business operation. The MEITIM project aims to fill this gap. An extensive market study will identify the professional profiles needed in the sustainable mining industry and a feasibility study will assess the possibilities and implementation of the new master's program. The three-year nature of the planned study is a response to the globalization and internationalization of the mining sector, where the art of adapting to changes and the ability to work in a multicultural environment is important. Based on the results of market analysis and feasibility studies, a completely new, interdisciplinary, industry-driven master's program will be defined. This will aim to educate a new generation of specialists with deep technical knowledge in the raw materials sector, able to combine this knowledge with the practical ability to integrate innovation and modern technological solutions with real business solutions in sustainable mining.

The basic assumptions of the MEITIM program at the master's level include:

- Increase the creativity and innovative capacity of engineers;

- Through practical courses, the provision of in-depth knowledge of the technologies that are introduced in the basic value chain of raw materials (geology, mining, mineral processing and metallurgy). This will allow them to understand the technical, business, social and economic aspects, as well as the innovation and entrepreneurship in the raw materials sector;

- Stimulating technological innovation and integrating technology with a vision of creating new opportunities and added value;

- Increasing competence in entrepreneurship and business activities;

- To expand the EIT KIC Raw Materials expert community in this dynamic and innovative sector of activity;

- To complement the training profile of T-shaped specialists.

This will train engineers who can successfully develop technology integration projects from the smallest mines to the largest international mining companies. Personnel trained under the MEITM program, aware of the latest technological potential and the challenges facing the mining industry in Europe and the world in connection with Agenda 2030 and Green Deal, will be ready for the technological transformation of the raw material industry.

\section{Summary and Conclusions}

This article discusses several important issues related to the current situation of the mining industry regarding education in Poland. This presents a diagnosis of the current state of Polish higher education in the field of mining, e.g., at Wroclaw University of Science and Technology (WUST) concerning the statistics of Spanish and Finnish universities. Based on these juxtapositions, a decreasing trend and less and less interest of students in mining majors at Polish universities have been noticed in recent years. This translates into a smaller number of graduates (at all levels of education) ready to work in mines. This trend applies to all the listed technical universities in Poland which pursue mining studies. In Spanish universities as a whole, the demand for the title of mining engineer has also been decreasing in recent years, both for undergraduate and graduate studies. An exception was the situation at the Technical University of Madrid, where there has been an increase in interest. In addition to its advantageous location (capital city), the University has a wide range of undergraduate courses offered by the School of Mining Engineers, supported by strong mining traditions. Finnish statistics differ from the Polish and Spanish data due to, among others, courses covering only mining subjects. An example is LUT, which implements a chemical engineering program including mining studies (not as its own, 
separate mining studies program). This is the situation at other technical universities in Finland, except the University of Oulu, where there is an own program for mining and mineral processing. Due to, among others, the tradition of doing a master's theses in industry or research projects at a Finnish university, paid from a salary or a scholarship, interest among students is not decreasing. The combination of experience within the MEITIM project may be an opportunity to increase the attractiveness of mining courses towards sustainable mining in the teaching process, especially in Poland. This article shows that there is a link between the condition of the mining industry in Poland and the number of people who want to study mining. The authors [23] indicate the possibilities of the development of mining investments in Poland by combining them with investment attractiveness, which also indicate the main factors and barriers and conditions that shape them.

The universities must train engineers capable of meeting social demands in the fields related to their scope of activity. Moreover, they must educate professionals who are motivated and committed to conduct safety, sustainability and solidarity at work; versatile, flexible, creative and competitive professionals, capable of acting nationally and internationally and adapting to continuous scientific-technological changes; competent both to direct and manage a company. The inclusion of several guidelines and arrangements for key sectoral competences, including those of the European Commission and the International Council for Mining and Metals, in education programs supporting the objectives of sustainable development in innovative mining may help to halt the decline in interest in mining.

Author Contributions: Conceptualization, M.W.-K., J.W. and J.H.H.; methodology J.G.-Z. and J.K.-K.; formal analysis, D.S., G.P. and B.K.; investigation, A.G., A.H. and M.A.M.; data curation, J.G.-Z., K.A.-P., J.W., M.L. and R.T.; writing—original draft preparation, J.W., J.G.-Z., M.W.-K., J.H.H., R.T.; writing-review and editing, M.W.-K.; D.S., K.A.-P., A.G.; visualization, J.G.-Z., J.K.-K. and D.S. All authors have read and agreed to the published version of the manuscript.

Funding: This activity has received funding from the European Institute of Innovation and Technology (EIT), a body of the European Union, under the Horizon 2020, the EU Framework Programme for Research and Innovation. This work is supported by EIT Raw Materials GmbH under Framework Partnership Agreement No. 19116 (MEITIM. Master in Entrepreneurship, Innovation and Technology Integration in Mining, implemented under KAVA 6-Education).

Acknowledgments: Jukka-Pekka Ranta from the University of Oulu is gratefully acknowledged for providing data of Oulu Mining School.

Conflicts of Interest: The authors declare no conflict of interest.

\section{References}

1. Communication No. 640, 2019. In The European Green Deal; (COM no. 640, 2019); Commission of European Communities: Brussels, Belgium, 2019.

2. Smol, M.; Marcinek, P.; Duda, J.; Szołdrowska, D. Importance of Sustainable Mineral Resource Management in Implementing the Circular Economy (CE) Model and the European Green Deal Strategy. Resources 2020, 9, 55. [CrossRef]

3. Pędziwiatr, E.; Kulczycka, J. Oferta edukacyjna polskich uczelni technicznych w obszarze CSR. Horyzonty Wychowania 2018, 17, 93-102. [CrossRef]

4. Pactwa, K.; Woźniak, J. Knowledge of CSR issues among mining business stakeholders and the academic environment-Case study from Poland. Gospodarka Surowcami Mineralnymi Miner. Resour. Manag. 2020, 36, 149-166.

5. ICMM. 2020. Available online: https://www.icmm.com/website/publications/pdfs/mining-principles/miningprinciples.pdf (accessed on 14 June 2020).

6. INTERMIN. 2019. REPORT ON SKILLS GAPS. Available online: https://interminproject.org/wp-content/ uploads/D2.1.pdf (accessed on 17 June 2020).

7. Hartlieb, P.; Jorda Bordehore, L.; Regueiro y González-Barros, M.; Correia, V.; Vidovic, J. A comprehensive skills catalogue for the raw materials sector and the structure of raw materials education worldwide. Min. Technol. 2020, 129, 1-13. [CrossRef] 
8. Chikatamarla, L.; Prasad, D.N. Emerging Mining Trends: Preparing Future Mining Professionals. In International Conference on Emerging Trends in Engineering (ICETE); Satapathy, S., Raju, K., Molugaram, K., Krishnaiah, A., Tsihrintzis, G., Eds.; Learning and Analytics in Intelligent Systems; Springer: Cham, Switzerland, 2020; Volume 2.

9. Lorenc, S.; Sorokina, O. Sustainable development of mining enterprises as a strategic direction of growth of value for stakeholders. Min. Sci. 2015, 22, 67-78.

10. Rocznik Statystyczny Pracy. Yearbook of Labour Statistics, Branch Yearbooks; Dmochowska, H., Ed.; Central Statistical Office: Warsaw, Poland, 2012.

11. Rocznik Statystyczny Pracy. Yearbook of Labour Statistics, Branch Yearbooks; Dmochowska, H., Ed.; Central Statistical Office: Warsaw, Poland, 2013.

12. Rocznik Statystyczny Pracy. Yearbook of Labour Statistics, Branch Yearbooks; Dmochowska, H., Ed.; Central Statistical Office: Warsaw, Poland, 2015.

13. Rocznik Statystyczny Pracy. Yearbook of Labour Statistics, Branch Yearbooks; Rozkrut, D., Ed.; Central Statistical Office: Warsaw, Poland, 2017.

14. Rocznik Statystyczny Pracy. Yearbook of Labour Statistics, Branch Yearbooks; Rozkrut, D., Ed.; Central Statistical Office: Warsaw, Poland, 2019.

15. Rocznik Statystyczny Przemysłu. Statistical Yearbook of Industry-Poland, Branch Yearbooks; Dmochowska, H., Ed.; Central Statistical Office: Warsaw, Poland, 2010.

16. Rocznik Statystyczny Przemysłu. Statistical Yearbook of Industry-Poland, Branch Yearbooks; Rozkrut, D., Ed.; Central Statistical Office: Warsaw, Poland, 2020.

17. CSO. Central Statistical Office in Poland. Available online: http://stat.gov.pl (accessed on 17 August 2020).

18. The Regulation of the Council of Ministers of 24 December 2007, on the Polish Classification of Activities (Journal of Laws No. 251, Item 1885). Available online: https://stat.gov.pl/download/gfx/portalinformacyjny/ en/defaultstronaopisowa/3249/1/1/poz_regulation_pkd.pdf (accessed on 5 October 2020).

19. Agencia Nacional de Evaluación de la Calidady Acreditación-ANECA (n/d). Libro Blanco del Título de Grado en Ingeniería de Minas y Energía". Available online: http://www.aneca.es. (accessed on 12 October 2020).

20. Fundación CYD. Las Universidades Españolas. Una Perspectiva Autonómica. 2019. 2020. Available online: https://www.fundacioncyd.org/ (accessed on 5 October 2020).

21. Fundación CYD. Las Universidades Españolas. Una Perspectiva Autonómica. 2018. 2019. Available online: https://www.fundacioncyd.org/ (accessed on 5 October 2020).

22. Fundación CYD. Las Universidades Españolas. Una Perspectiva Autonómica. 2017. 2018. Available online: https://www.fundacioncyd.org/ (accessed on 1 October 2020).

23. Kulczycka, J.; Nowaczek, A.; Hałasik, K.; Whirt, H.; Szkop, R. The analysis of factors, barriers and conditions that affect the attractiveness of mining investment in Poland-own research. Min. Sci. 2017, 24, 209-226.

Publisher's Note: MDPI stays neutral with regard to jurisdictional claims in published maps and institutional affiliations.

(C) 2020 by the authors. Licensee MDPI, Basel, Switzerland. This article is an open access article distributed under the terms and conditions of the Creative Commons Attribution (CC BY) license (http://creativecommons.org/licenses/by/4.0/). 